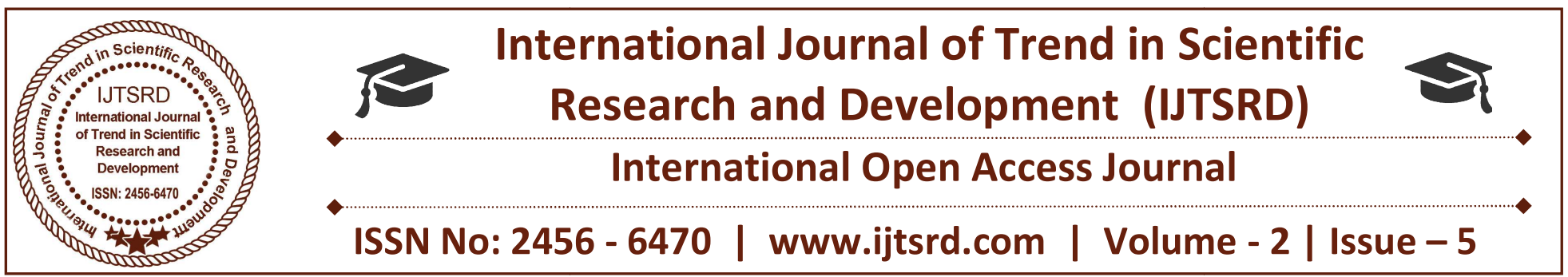

\title{
The Right to Information Act : An Effective Tool or An Illusion
}

\author{
Saket Dev Pandey \\ B.B.A., L.L.B. (Hons), Indore Institute of Law, \\ Indore, Madhya Pradesh, India
}

\section{ABSTRACT}

The Right to Information Act is not a General Law it is a unique set of Rules having an uncommon Nature in respect with rest of the Laws or Acts. Right to information have been made with an objective of proper transparency that provides a proper understanding of a topic in which an Individual is Interested. The Basic objective of Right to Information is to curb the issue that comes during the Regime of a Government or any authorized body. often express our views over the work done by the Government or the actions taken by them, In old times people or Citizens may only discuss at a guessing that was based on an Individuals sense of Understanding or Opinions, but the situation Changed after the enforcement of Right to information Act, Now You can Discuss the Issues as you have Right to know and being aware about the action and the concept at which the proclamation is based. Proper transparency to the beneficiaries (Public) from the acts of the Ruling Body is a need of Hour. As the Corruption is on its peak, proper Eradication of such big issue is important and Right to Information is one of the most influential and an important one. It has been made with an objective of Transparency and Eradication of corruption and more related topics, but this theme also comes with a sign of question marks whether it really goes as its objective are?

Right to Information is a Fundamental Right, that makes it different from other set of acts, It is been guaranteed as per Article 19 and 21 of the Constitution of India. It is the part of the Fundamental Right to Freedom of Speech and Expression recognized by the Constitution of India and Various Supreme Court Decisions. It plays a major role in the attainment of Economic, social and Political rights of an Individual as well as community at large. Covering all the areas and Sections of the countries it has been an effective tool in the recent years. Right to Information is effective at each and every part of India.

However it can be said without any hesitation that India has finally woken up to realize that right to Information is a key component in the attainment of all the required Goals of the Nation.

\section{INTRODUCTION}

India always took pride in being the Largest Democracy, but with the passing of Right to Information act in 2005.It has also become an Accountable, Interactive and Participatory Democracy. Right to Information made the status of India more prominent at the International Level, India being the Largest Democracy is always in the eyes of International Diplomacy, with such a Huge Population Commencement of such Act proved that Population is not a factor for any action taken in the Benefit of its Individuals. It is a law provided by the Parliament of India giving Citizens of India access to records of the Central Government and State Governments.

The Act applies to all States and Union Territories of India, Except the State of Jammu and Kashmir Which is covered under a State Level Law. Under the Provision of the Act, any Citizen (Including the Citizens within Jammu and Kashmir) may Request Information from a Public authority (A body of Government or 'Instrumentality of State) which is required to reply expeditiously or within thirty days. The Act also requires every Public authority to computerize their records for wide dissemination and to proactively publish certain Categories of 
Information so that the Citizens need minimum recourse to request Information formally.

\section{Historical Background}

The RTI laws were first successfully Enacted by the State Governments - Tamil Naidu (1997), Goa (1997), Rajasthan (2000), Karnataka (2000), Delhi (2001),Maharashtra (2002), Madhya Pradesh (2003), Assam (2002) and Jammu and Kashmir (2004). The Maharashtra and Delhi State Level enactments are considered to be the most widely used among all the States. ${ }^{1}$

Before this Act the accountability of Public Authority was minimal. The people who voted for the formation of Democratically Elected Government and Paid taxes to the Finance Public Activities had no Legal rights to Know as to what process has been followed in framing the policies affecting them, how the programs have been Implemented, Who are the Concerned Officials related or associated to the decision making process and Execution of the Schemes and why the promises made for the delivery of essential Goods and Services to the poor have not been fulfilled?

The Right to Information gave Citizens Right or you can say power to perform their Rights in a Democratic Country. Now they may get access in whatever Fields they desire, But one major Requirement is to be aware about the basic facts related to the Field you want Information in, because

Without awareness and because of Ignorance the information is only a piece of paper and Data. Indian Constitution has provided a great platform to perform right and if done in a proper manner it may create a huge difference in the proper running of the Administrative policies as well as for the shake of Public Policies and for the benefits of Citizens.

\section{Results and Discussion}

\section{Salient Features of Right to Information}

The Right to Information is a well calculated and Formulated Act. It is based on the principle of transparency in Democracy. It has already given a platform to the citizen to perform well being in the favour of the Society. The Right to Information Act contains Six Chapters and two Schedule. Chapter one is entitled and explains the various terms like

\footnotetext{
${ }^{1}$ https://www.scribd.com/doc/20595082/Research-Paper-onRight-to-Information-Act-2005 ( last visited at 03:17 P.M dated on 24-jun-18)
}

appropriate government, public authority, information, record, third party etc. Chapter 2 contains obligations of public authorities. Chapter 3 deals with the Central Information Commission while Chapter 4 describes State Information Going in the same order let's move to the fifth one,

Commissions. Chapter 5 is about the powers and functions of the Information Commissions,

Appeals and penalties and Chapter 6 has all the miscellaneous things. Schedule 1 contains the

oath to be taken by various levels of Information Commissioners. Schedule 2 contains a list of

Intelligence and security organizations established by the Central Government. RTI is for the

Right of any citizen of India to request access to information and the corresponding duty of

Government to meet the request except the exempted in formation (Sec.8/9),

"right to information" means the right to information accessible under this Act which is held by

right under the control of any public authority and includes the right to

1. inspection of work, documents, records;

2. "taking notes, extracts or certified copies of documents or records

3. taking certified samples of material

So these are some Features related to Right to Information, as already mentioned above it is a well formulated account of Act that imposes accountability over the person making the decision for the Individuals.

After reading the Features let's see what are the issues related to Right to Information, or we can Say what are the challenges that authority have to overcome ${ }^{2}$

\section{Issues and Challenges to Right to Information Act 2005}

1. Ambiguous orders

2. Lack of proper procedure for recording orders.

\footnotetext{
2 Afro Asian Journal of Social Sciences

Volume 1, No. 1 Quarter IV 2010

ISSN 2229 - 5313 Page -4
} 
3. Total lack of accountability as to when written orders will be given.

4. No penalties imposed even on PIOs who have denied information without any justification.

5. Arbitrary refusal of information for reasons not justified by the RTI Act.

6. Information Commissioners arguing on behalf of public authority, manufacturing imaginary justifications for denial of information when PIOs are not present to represent their own case.

So these are the Basic hurdles in the proclamation of the respective Act.

\section{Understanding RTI with the help of Data}

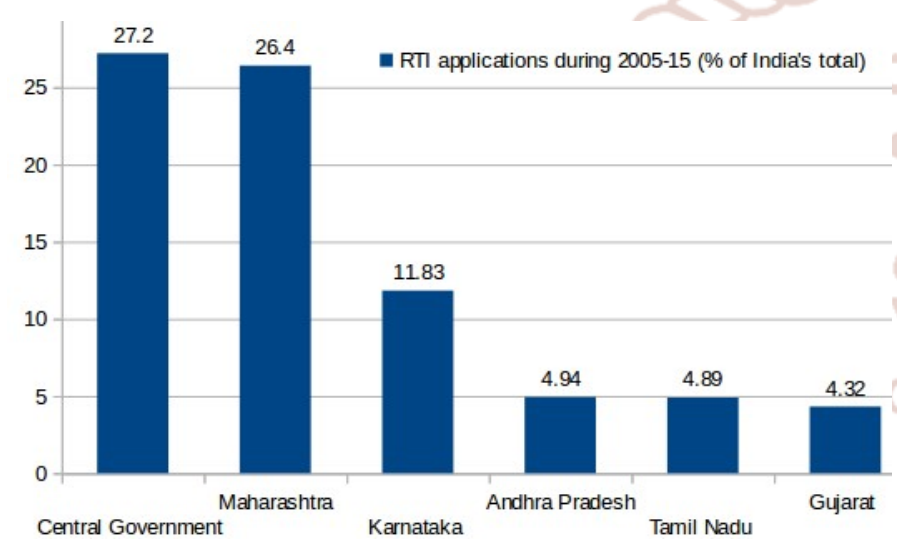

Here is the data that provides the applications during Year 2005-15,Most Number of applications have been registered against the Central government, that is obvious to as it is the only body that look after the nation, going in list Maharashtra comes at second Position with 26.4 numbers of Applications. In order we also have Karnataka, Andhra Pradesh, Tamil Nadu, Gujarat, The Interesting thing that can be witnessed till 2018 that the state with higher literacy rate are more in registering the Application, thus shows the Basic need or also the loopholes in other manner as only educated people may understand the concept and the effects of Right to Information. State Like Uttar Pradesh or Bihar with a huge and Dense population are far behind in terms of registering the application and the only thing that can be concluded or you can say noticed is the less awareness about the concept of Right to Information as well as ignorance. After focusing at the Number of Application let's Focus at the effects of such application, yes I am Talking about the cases, the cases that reflects the prominent nature of Right to Information, Here we have some Landmark cases.
List of Few Landmark Cases in terms of Right to Information Act 2005 decided by the Supreme Court of India

1. People's Union For Civil Liberties (PUCL) And Another, Petitioner V. Union Of India And Another, With Lok Satta And Others, V. Union Of India, 2003(001) SCW 2353 SC

2. Union Of India V. Association For Democratic Reforms And Another, With People's Union For Civil Liberties (PUCL) And Another, V. Union Of India And Another, 2002(005) SCC 0361SC

3. Union Of India And Others, V. Motion Picture Association And Others, 1999(006) SCC 0150 SC

4. Dinesh Trivedi, M.P. And Others V. Union Of India And Others, 1997(004) SCC 0306SC

5. Tata Press Ltd., V. Mahanagar Telephone Nigam Limited And Others, 1995(005) SCC 0139 SC

6. Secretary, Ministry Of Information \& Broadcasting, Govt. Of India, And Others, V. Cricket Association Of Bengal And Others, 1995(002) SCC 0161 SC

7. Life Insurance Corporation Of India, V. Prof. Manubhai D. Shah, 1992 (003) SCC 0637 SC

8. Reliance Petrochemicals Ltd., V. Proprietors of Indian Express Newspapers, Bombay Pvt. Ltd. And Others, 1988 (004) SCC 0592 SC

9. Sheela Barse, V. State Of Maharashtra, 1987 (004) SCC 0373 SC

10. Indian Express Newspapers (Bombay) Private Ltd., And Others, V. Union Of India And Others, 1985 (001) SCC $0641 \mathrm{SC}^{3}$

Here are some Landmark cases that were decided by the Supreme Court of India related to Right to Information Act, After a brief study of the Cases one thing I have found that no matter how many cases are pending, how many applications are still not accepted but one thing can be clearly said that the Judiciary is playing a significant role in the enforcement as well as the administration of the Right to Information. The above Cases also Includes a number of High Profile Cases but the court has shown its ruthless nature in providing Decisions.

As we all know role of Judiciary is always an important factor when comes to law or Acts here also going with its nature, Judiciary has been proved determined towards the seriousness of this act and have played a Significant role in providing a fare and accessible platform to the citizens of India. Cases

http://www.humanrightsinitiative.org/programs/ai/rti/india/cas es.pdf 
from Different States as well as against the union and their decisions have given a sense of Confidence to the people of India

\section{Process to Seek right to Information in India}

1. You can seek information under RTI Act- 2005 from any Public Authority (government organization or government aided organization) Application can be handwritten or typed. Application form can be downloaded from India Development Gateway Portal (Pdf file)

2. Application should be submit in English, Hindi or any other state languages

3. Provide following information in your application:

Name and office address of Assistant Public Information Officer (APIO)/Public Information Officer (PIO)

$>$ Subject: Application under-Section 6(1) of Right to Information Act- 2005

Particular of information you want from public authority Applicant Name

Father's/Husband's Name

Category- SC/ST/OBC

Application Fee

Do you Come from BPL family- Yes/No,

$>$ Postal address with mobile No and e-mail ID (Mobile No and e-mail ID is not mandatory)

$>$ Date and place

$>$ Applicant signature

List of enclosures

So these are some of the basic requirements that one has to go through while the registration of the application.

\section{Right To Information Act - A tool against Corruption or Just an Illusion}

From last few decades a large number acts and Laws have been introduced as well as made for curbing the biggest disease of an administrative world and that is Corruption. Right to Information have also been introduced with an objective of Eradication of Corruption from the nation, now let's focus that is it true, Right to Information works as a weapon against Corruption? The right of citizens to know what governments, international organizations and private corporations are doing, and how public resources are allocated, directly reflects anti corruption concerns. Corruption flourishes in darkness and so any progress towards opening governments and intergovernmental organizations to public scrutiny is likely to advance anti corruption works. So from this Statement one thing is clear that Right to Information is active in accordance with its nature and yes of course Corruption requires transparency to get eradicated and for that matter nothing is better than Right to Information.

\section{Right to Information - An Illusion having fake publicity or Failure of RTI Act 2005}

Being the Biggest hope or weapon against corruption the act makers had a huge expectation from Right to Information Act but it didn't went as decided so far. It aims to provide all the information related to the need or desires of an Individuals, Process goes in the same way but ones the application is registered it starts taking a huge amount of time to get processed. It's a fact that everything comes with an odd but at this stage corruption cannot be eradicated by a weapon itself damaged. Let's focus on some of the major issues that comes under way while the performance of right to information act -

The RTI Act is not just a law promoting disclosure of information but a strategy to improve delivery of public services through citizen-enforced accountability. Disclosure of information is the rule and exemption an exception under it. Section 4 of the Act mandates pro-active disclosure of basic information about the department, such as the names of the Minister concerned, key staff, contact details, organizational structure, the services provided and programs run, the departmental budget and ongoing updates on expenditure and public procurement, among other things. However, the structure and dynamics of public administration have changed from welfare to regulatory to commercial activities. The government holds a lot of sensitive information, the disclosure of which may not, at all times, be in the interest of the nation or the State or serve any public interest. While the call for open government data endorses the proactive disclosure requirement under the RTI Act, there is a need to develop a robust information disclosure policy to mitigate the unintended consequences of open data while fostering transparency in public administration. The Official Secrets Act, 1923 typically provides legal embargo against espionage and unauthorized disclosure of information relating to security and intelligence (which anyway qualify for exemption from disclosure under the RTI Act) and is subject to damage assessment. 
Based on the sensitivity of the information held by the Public Authority, it is classified and treated as per Sec $156 \& 157$ of State Secretariat Office Manual as top secret, secret and confidential (care being taken to ensure that the Top Secret category is not unnecessarily employed). Whereas under the RTI Act, exemptions set out under Sections 8, 9 and 24 form the only basis for refusing access to government information requested under the Act.

The said exemptions are either mandatory or discretionary and can be disclosed if public interest in disclosure outweighs the harm to protected interests of the RTI Act. However, an administrative authority in which discretion is vested is supposed to exercise it by taking relevant considerations into account and by excluding irrelevant considerations. And it is a settled position of law that the decision of an administrative body is subject to judicial review if it has not exercised its discretion legally.

So what needs to be considered under the public interest test? Factors favouring disclosure of information are government accountability, public participation, public awareness and promoting human rights. Factors favouring non-disclosure are invasion of privacy, statutory prohibition and other exemptions under Sections 8, 9 and 24 of the Act and factors that are irrelevant for consideration under the Public Interest Test are: a) that the information may be misused, misinterpreted or misunderstood by the applicant; and b) that the disclosure might cause embarrassment to the government. ${ }^{4}$

\section{Conclusion}

The Right to information is surely one of the most important and highly needed act and an achievement in the legal history of India. It has already proved its significant role in the cases that have been illustrated in the given research paper. It has given a platform to the Citizens for a better understanding of Indian Constitutional body as well as Public Official Working Body. It has also proved its effects in the eradication of Corruption in recent years but it also came with some loopholes let's sum up this debate by focusing at some of the key points related to its benefits and its loopholes -

\section{Cons}

RTI is the one \& only cause of murder of many innocent but daring \& true nationalists called

http://www.humanrightsinitiative.org/programs/ai/rti/articles/ using_rti_as_anti_corruption_tool.pdf
Corruption Crusaders. If there was no such law then probably all those were alive $\&$ would have contributed more to the society.

$>$ It has legitimized the act of few people to extort or blackmail the wrong doers \& make millions of money. A prominent lawyer \& expelled founding member of a newly formed political party is one such example.

It has caused too much money to the exchequer particularly the tax payer as many people filing senseless RTI \& wasting Government time, money \& efforts.

\section{Pros}

All large scams \& scandals in past 12 yeasssssssssssssrs has been outcome of RTI Act 2005. From $2 \mathrm{G}$ to Coalgate etc.

Because it our Governments are more accountable $\&$ answerable to the public.

Because of RTI we can have details of our "highly educated" politician's particularly supremely authentic degrees of those much popular ministers. ;-)

And the most important one, it has empowered the common to exercise it's authority over his servants means the bureaucrats \& politicians, alike.

So this was all about the Right to Information Act $2005 .^{5}$

\section{References}

Books used

Professional's Right to Information Act, 2005 Bare Act

THE RTI STORY, POWER TO THE PEOPLE (ENGLISH, Paperback, ARUNA ROY with the MKSS Collective)

Guide on Right to Information Act 2005

\section{Websites Visited}

https://www.scribd.com/doc/20595082/ResearchPaper-on-Right-to-Information-Act-2005

http://www.humanrightsinitiative.org/programs/ai/ $\mathrm{rti} /$ india/cases.pdf

http://www.humanrightsinitiative.org/programs/ai/ rti/articles/using_rti_as_anti_corruption_tool.pdf

https://www.quora.com/What-are-pros-and-consof-the-Right-to-Information-Act

\footnotetext{
${ }^{5}$ https://www.quora.com/What-are-pros-and-cons-of-theRight-to-Information-Act
} 